\title{
MANAJEMEN RISIKO KEBIJAKAN INFRASTRUKTUR PEMBANGUNAN DI INSTITUT TEKNOLOGI SUMATERA
}

\section{RISK MANAGEMENT OF INFRASTRUCTURE DEVELOPMENT AT THE SUMATRA INSTITUTE OF TECHNOLOGY}

\author{
Rifky Febrihanuddin ${ }^{1}$, Noverman Duadji, Suripto ${ }^{2}$, Intan Fitri Meutia ${ }^{3}$ \\ Magister Ilmu Administrasi, Universitas Lampung \\ Email: rifkyfebri1@gmail.com
}

Dikirim 15 Juni 2020, Direvisi 10 Juli 2020; Disetujui 27 Juli 2020

\begin{abstract}
Abstrak: Percepatan kebijakan pembangunan infrastruktur di Institut Teknologi Sumatera memiliki potensi risiko sehingga diperlukannya manajemen risiko. Tujuan penelitian ini untuk mengetahui bagaimana manajemen risiko kebijakan pembangunan infrastruktur di Institut Teknologi Sumatera. Metode penelitian yang digunakan adalah eksplanatoris konkruen dengan pendekatan mixed methods. Teknik pengumpulan data dengan memberikan kuesioner kepada 45 responden dan melakukan wawancara kepada 6 informan. Hasil dari penelitian ini risiko signifikan berdasarkan aspek technical feasibility yaitu sebuah kebijakan dapat berjalan jika pelaksana dapat memahami kebijakan yang sudah disahkan sebesar $56.6 \%$ artinya risiko sedang, pimpinan beserta pelaksana memiliki banyak metode dalam implementasi kebijakan sebesar $65.5 \%$ artinya risiko tinggi, institusi mendapat dukungan dari pihak masyarakat dan civil society sebesar 53.5\% artinya risiko sedang. Risiko signifikan berdasarkan aspek political viability yaitu sebuah kebijakan dapat berjalan jika pelaksana dapat memahami kebijakan yang sudah disahkan sebesar $49.4 \%$ artinya risiko sedang, pimpinan beserta pelaksana memiliki banyak metode dalam implementasi kebijakan sebesar $46.6 \%$ artinya risiko sedang, perselisihan antara institusi dengan kontraktor sebesar $62.7 \%$ artinya risiko tinggi, institusi mendapat dukungan dari pihak masyarakat dan civil society sebesar $59.4 \%$ artinya risiko sedang. Berdasarkan hasil tersebut dapat disimpulkan bahwa risiko dapat dimitigasi dengan melakukan sosialisasi, koordinasi dan komunikasi antar pihak.
\end{abstract}

Kata Kunci: Percepatan Pembangunan, Analisis Risiko, Manajemen Risiko

\begin{abstract}
The acceleration of infrastructure development policy at the Sumatra Institute of Technology has the potential for risk so that the need for risk management. The purpose of this study is to find out how the risk management of infrastructure development policies at the Sumatra Institute of Technology. The research method used is concurrent explanatory with mixed methods approach. Data collection techniques gived questionnaires to 45 respondents and conducted interviews with 6 informants. The results of this research are significant risks based on technical feasibility aspects, namely a policy can run if staff can understand the policies that have been passed by $56.6 \%$ means medium risk, leaders and employees have many methods in implementing policies of $65.5 \%$ meaning high risk, institutions get support from $53.5 \%$ of the community and civil society means moderate risk. Significant risk based on political viability is a policy that can run if employees can understand the policy that has been approved by $49.4 \%$ means that the risk is moderate, leaders and employees have many methods in implementing the policy of $46.6 \%$ means that the risk is moderate, the dispute between the institution and the contractor is $62.7 \%$ meaning Tinggi risk, the institution has the support of the community and civil society by $59.4 \%$ means Sedang risk. Based on these results it can be concluded that risks can be mitigation by conducting socialization, coordination and communication between parties.
\end{abstract}

Keywords: Acceleration Development, Risk Analysis, Risk Management.

\section{PENDAHULUAN}

Pembangunan hingga sampai saat ini menjadi sesuatu yang sangat menarik untuk diperdebatkan. Pembangunan sebagai upaya terkoordinasi untuk menciptakan lebih banyak alternatif bagi setiap warga negara untuk memenuhi dan mencapai aspirasi paling manusiawi. Dapat ditafsirkan secara singkat bahwa pembangunan harus berorientasi pada keanekaragaman dalam semua aspek kehidupan di masyarakat. Mekanisme ini menuntut pembentukan lembaga hukum yang kredibel sehingga mereka dapat memainkan peran yang adil. Pembangunan 
dimulai dari proses perubahan dalam strata sosial komunitas besar dan berkelanjutan. Pembangunan menurut Soekanto (2006:382), selain memiliki tujuan yang diinginkan, pembangunan bukan tidak mungkin, sehingga berdampak pada subsistem sosial.

Perubahan strata sosial dimulai dari proses keinginan untuk berubah lebih maju atau bisa dimulai dari proses mandiri. Komunitas itu sendiri harus cukup berani untuk membuat keputusan dalam pembangunan. Partisipasi masyarakat dalam proses pembangunan akan menciptakan perubahan sosial yang berkembang secara dinamis. Dalam hal disiplin ilmu ekonomi, pembangunan adalah proses bisnis yang menyebabkan pendapatan per kapita masyarakat meningkat dalam jangka panjang (Sukirno, 2007: 13). Secara sederhana pembangunan sering diartikan sebagai upaya untuk bergerak menuju perubahan yang lebih baik, karena perubahan yang dimaksud adalah menuju perbaikan dari keadaan semula, tidak jarang ada juga yang menafsirkan bahwa pembangunan juga tumbuh. Pertumbuhan bisa dalam bentuk pembangunan yang dilakukan oleh komunitas tertentu di komunitas tersebut.

Masyarakat sebagai orang yang menempati suatu wilayah dan merupakan aset pembangunan dapat disebut sebagai Sumber Daya Manusia (SDM). Pertumbuhan populasi yang cepat menyebabkan kepadatan populasi yang tinggi. Sehubungan dengan pertumbuhan populasi yang tinggi, ini merupakan masalah dalam kehidupan manusia seperti kepadatan populasi. Kepadatan populasi menyebabkan beberapa dampak. Salah satunya adalah meningkatkan kebutuhan akan akses yang adil terhadap pendidikan. Masalah ini dielakkan oleh pemerintah untuk terus berupaya mengembangkan pendidikan, khususnya distribusi pendidikan tinggi yang merata di seluruh Indonesia. Pendidikan tinggi yang pada awalnya berkembang pesat hanya di Pulau Jawa, saat ini pemerintah akan fokus pada pengembangan pendidikan tinggi di luar Pulau Jawa, salah satunya adalah Sumatera.

Selama beberapa dekade, di Indonesia hanya ada dua institut teknologi milik pemerintah. Di sisi lain, pertumbuhan industri di Indonesia terkait dengan ketersediaan sumber daya alam untuk tumbuh pesat di luar Jawa, di mana pertumbuhan industri ini membutuhkan dukungan insititut teknologi. Pemerintah melalui Kementerian Pendidikan dan Kebudayaan telah mendirikan pendirian institut teknologi yakni Institut Teknologi Sumatera. Institut Teknologi Sumatera memiliki beberapa potensi besar dalam pengembangannya, salah satunya adalah bahwa Institut Teknologi Sumatera adalah satu-satunya institut teknologi negeri di Sumatera, dan termasuk dalam bidang pengembangan strategis. Dalam hal ini, kebijakan pengembangan sumber daya manusia yang unggul, berkualitas, penguasaan ilmu pengetahuan dan teknologi, selain memiliki karakter kewirausahaan yang baik adalah komponen yang sangat penting.

Kebijakan umumnya dipahami sebagai keputusan yang diambil untuk menangani hal-hal tertentu. Namun kebijakan bukan hanya keputusan yang diambil. (Rose dalam Hamdi, 2014: 36). Kebijakan publik dipahami sebagai hasil dari apa yang disebabkan oleh masyarakat, sehingga kebijakan publik adalah kumpulan ide-ide komunitas yang menyediakan bentuk ruang publik yang sangat erat kaitannya dengan aktor masyarakat yang mempengaruhi dan menginformasikannya (Dinham, 2009: 50). Oleh karena itu, pentingnya proyeksi untuk mengelola risiko semua hal yang akan terjadi dalam proses kebijakan pembangunan infrastruktur di Institut Teknologi Sumatera. Manajemen risiko adalah pendekatan sistematis untuk menemukan risiko potensial untuk mengurangi kasus yang tidak terduga. Manajemen risiko harus bersifat preventif dengan didukung informasi yang akurat. 
Proses ini merupakan langkah pencegahan di mana kondisi bisnis yang sebenarnya dapat menjadi jelas sebelum terlambat dan dapat menghindari kegagalan yang lebih besar (Kerzner, 2001: 224). Perencanaan yang berhasil dalam setiap kebijakan harus dipikirkan dan dipertimbangkan dengan hati-hati, artinya pemerintah harus memikirkan bagaimana memetakan risiko yang akan terjadi dari pembangunan tidak menyebabkan konflik dan berhasil memenuhi kebutuhan. Keberhasilan manajemen risiko tergantung pada efektivitas kerangka kerja yang digunakan untuk memberikan dasar-dasar dan pengaturan dalam organisasi di semua tingkatan. Kerangka kerja ini dapat membantu kita mengelola risiko secara efektif melalui penerapan proses manajemen risiko di berbagai tingkatan. Berdasarkan latar belakang masalah di atas, penelitian ini bertujuan untuk mengetahui bagaimana analisis risiko kebijakan pembangunan infrastruktur di Institut Teknologi Sumatera.

\section{TINJAUAN PUSTAKA}

\section{Kebijakan Publik}

Kebijakan (policy) umumnya dipahami sebagai keputusan yang diambil untuk menangani hal-hal tertentu. Namun kebijakan bukanlah sekedar suatu keputusan yang ditetapkan. (Rose dalam Hamdi, 2014:36). Kebijakan publik dipahami sebagai akibat dari apa yang ditimbulkan oleh masyarakat, sehingga kebijakan publik itu merupakan kumpulan dari gagasan masyarakat yang memberikan bentuk ruang publik yang sangat erat hubungannya dengan aktor masyarakat yang mempengaruhi dan menginformasikannya (Dinham, 2009:50). Kebijakan publik pada akhirnya menyangkut pencapaian tujuan publik. Artinya, kebijakan publik adalah seperangkat tindakan pemerintah yang didesain untuk mencapai hasil-hasil tertentu yang diharapkan oleh publik sebagai konsistuen pemerintah. (Suharto, 2008:5).

Dalam pemaknaannya yang mengkaitkan dengan keputusan pemerintah ataupun tindakan pemerintah dengan maksud dan tujuan tertentu (Young dan Quinn dalam Suharto, 2008:43). Pelaksanaan kebijakan publik di Indonesia pada saat ini melibatkan banyak ahli kebijakan hanya berkenaan dengan birokrasi dan administrasi publik. Kebijakan tidak hanya melibatkan keputusan untuk memenuhi beberapa masalah tertentu, tetapi juga meliputi keputusan yang berkenaan dengan penyelenggaraan dan impelmentasinya. Secara konsep teoritis kebijakan publik merupakan serangkaian keputusan yang diambil oleh pemerintah dan tindakan yang dilaksanakan atau tidak dilaksanakan dalam rangka menyelesaikan masalah yang terjadi ranah publik.

Proses pembuatan kebijakan publik selalu diawali oleh serangkaian kegiatan yang saling bertautan dan berhubungan antara satu dengan yang lain. Proses tersebut terdiri dari kegiatan penyusunan agenda kebijakan, adopsi kebijakan implementasi dan evaluasi atau penilaian sebuah kegiatan kebijakan publik (Dunn dalam Madani, 2011:21).

\section{Manajemen Risiko}

Manajemen Risiko terlibat secara efektif dalam menghadapi ketidakpastian dengan risiko dan peluang yang berhubungan dan meningkatkan kemampuan organisasi untuk memberikan nilai tambah. Proses manajemen risiko dapat dibagi ke dalam 8 (delapan) komponen COSO Enterprise Risk Management, adalah sebagai berikut:

a. Lingkungan Internal

Lingkungan internal merupakan komponen instansi Pemerintah berada dan beroperasi. Cakupannya adalah kultur manajemen risiko, integritas, perspektif terhadap risiko, penerimaan terhadap risiko, nilai moral, struktur dan 
pendelegasian wewenang (Moeller, 2011:56).

\section{b. Penentuan Tujuan}

Manajemen harus menentukan objektif dari organisasi agar dapat mengidentifikasi mengakses dan mengelola risiko. Objektif dapat diklasifikasikan menjadi strategic objective di instansi Pemerintah berhubungan dengan pencapaian dan peningkatan kinerja instansi dalam jangka menengah dan panjang (Moeller, 2011:62).

c. Identifikasi Risiko

Mengidentifikasi kejadian yang berpotensial baik di lingkungan internal maupun ekternal organisasi yang mempengaruhi strategi atau pencapaian tujuan dari organisasi. Terdapat 4 model identifikasi risiko yaitu expoure analysis, environtmental analysis, threat scenario dan brainstorming questions (Moeller, 2011:66).

d. Penilaian Risiko

Sejauh mana dampak kejadian yang dapat mengganggu pencapaian dari objektif. Penilaian risiko dapat menggunakan dua teknik, yaitu: qualitative techniques menggunakan self-assessment questionnaires dan internal audit reviews (Moeller, 2011:71).

\section{e. Sikap atas Risiko}

Organisasi harus menentukan sikap atas hasil penilaian risiko yang meliputi; Avoidance, yaitu dihentikannya aktivitas atau pelayanan yang menyebabkan risiko. Reduction, yaitu mengambil langkahlangkah mengurangi dampak dari risiko. Sharing, yaitu mengalihkan atau menanggung bersama risiko dengan pihak lain. Acceptance, yaitu menerima risiko yang terjadi dan tidak ada upaya khusus yang dilakukan (Moeller, 2011:74).

\section{f. Aktifitas-aktifitas Pengendalian}

Penyusunan kebijakan dan prosedur untuk menjamin respon risiko terlaksana dengan efektif. Aktifitas pengendalian memerlukan lingkungan pengendalian yang meliputi; integritas dan nilai etika, kompetensi, kebijakan dan praktik-praktik SDM, budaya organisasi, filosofi dan gaya kepemimpinan manajemen, struktur organisasis serta wewenang dan tanggung jawab (Moeller, 2011:78).

\section{g. Informasi dan Komunikasi}

Fokus dari komponen ini adalah menyampaikan informasi yang relevan kepada pihak terkait melalui media komunikasi yang sesuai. Faktor-faktor yang perlu diperhatikan dalam penyampaian informasi dan komunikasi adalah kualitas informasi, arah komunikasi dan alat komunikasi (Moeller, 2011:81).

\section{h. Monitoring}

Monitoring dapat dilaksanakan baik secara terus menerus maupun terpisah. Aktifitas monitoring ongoing tercermin pada aktifitas supervisi, rekonsiliasi dan aktifitas rutin lainnya (Moeller, 2011:84).

\section{Prinsip Pencegahan Risiko}

Teknik dalam prinsip pencegahan risiko sejatinya terdapat dalam konsep analisis kebijakan yang dapat dikemukakan sebagai berikut:

Teknik discounting yang menghitung future value impak dari suatu kebijakan. Teknik three measures of efficiency, yaitu teknik evaluasi yang mengombinasikan tiga ukuran efisiensi: Nett Present Value atau discounted net benefits, benefits costs ratio, dan internal rate of return. Ketiga konsep ini sangat mudah ditemui pada teknik pengambilan kebijakan investasi atau rektrukturisasi bisnis Analysis sensitivitas, yaitu proses yang digunakan untuk menemukan asumsiasumsi yang bersifat kritikal atau sensitif terhadap analisis. Caranya dengan menguji setiap nilai yang masuk akal pada setiap variabel penting. Teknik yang digunakan biasanya digunakan untuk sektor bisnis, yaitu break event analysis, contongency analysis dan fortiary analysis. Ketiga teknik ini mempergunakan Nett Present Value 
(NPV) sebagai dasar perhitungannya (Patton dan Savicky dalam Nugroho,2017:658).

\section{Strategi Manajemen Risiko}

Manajemen risiko dalam kebijakan publik untuk mengantisipasi dan mengatasi risiko yang akan muncul baik pada saat perumusan, implementasi maupun evaluasi. Strategi manajemen ini termasuk strategi untuk melakukan distribusi sumber daya kebijakan, terdapat dua model dalam strategi manajemen risiko adalah sebagai berikut:

a. Regulatory Impact Assessment

RIA berperan memastikan secara sistematis dalam menentukan pilihan kebijakan yang paling efisien dan efektif. RIA dapat memberikan alasan perlunya intervensi pemerintah memberikan alasan bahwa regulasi adalah alternatif yang terbaik, memberikan alasan bahwa regulasi memberikan manfaat yang lebih besar dari biayanya. Review regulasi bertujuan menilai efektifitas kebijakan, memastikan bahwa perumusan kebijakan telah mempertimbangkan semua alternatif tindakan, meneliti berbagai manfaat dan biaya dan menilai secara strategis implementasinya (Nugroho,2017:625).

\section{b. Cost Benefit Analysis}

CBA atau anlisis biaya dan manfaat mengedepankan pemahaman bahwa setiap keputusan harus didasarkan kepada analisis apakah menghasilkan manfaat lebih banyak daripada biaya yang dikeluarkan. metode ini mengedepankan dalam kebijakan publik karena apapun kebijakannya. Cost Benefit Analysis lebih banyak digunakan untuk kepentingan proyek, terutama proyek infrastruktur (Nugroho,2017:625).

\section{Pemetaan Risiko}

Konsep pemetaan risiko merupakan kemampuan melihat sumber risiko berdasarkan faktor internal dan faktor eksternal yang dibagi ke dalam 4 (empat) kuadran, sebagai berikut:
Tabel 1. Tabel Kuadran Risiko

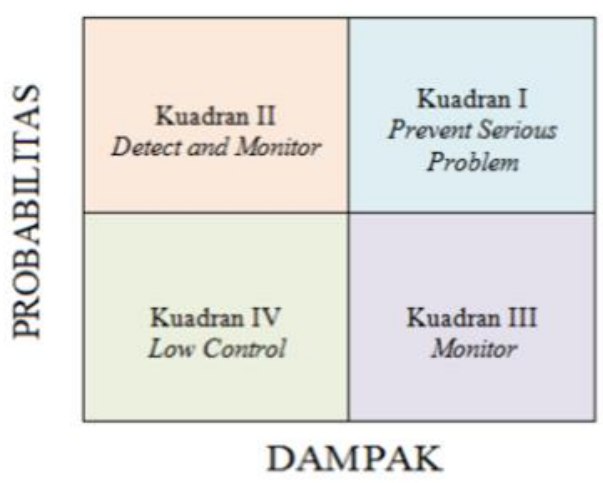

Pada gambar diatas menunjukan bahwa Kuadran I harus mendapatkan perhatian serius agar meminimalkan probabilitas dan dampak yang akan terjadi. Kuadran II membutuhkan rencana teruji untuk menjawab situasi risiko yang terjadi. Kuadran III memerlukan pengawasan intern untuk menjaga tingkat probabilitas dan dampak terjadinya risiko. Kuadran IV membutuhkan informasi teratur terhadap risiko yang terjadi.

\section{Percepatan Pembangunan Infrastruktur}

Pada hakikatnya sebuah percepatan pembangunan secara umum adalah proses perubahan yang terus menerus untuk menuju keadaan yang lebih baik sesuai dengan norma-norma tertentu. Mengenai pengertian pembangunan, para ahli memberikan definisi yang bermacammacam seperti halnya perencanaan. Istilah pembangunan bisa saja diartikan berbeda oleh satu orang dengan orang lain, daerah yang satu dengan daerah lainnya, Negara satu dengan Negara lain. Pembangunan itu sendiri pada hakikatnya adalah suatu proses sosial yang bersifat integral dan menyeluruh baik berupa pertumbuhan ekonomi maupun perubahan sosial demi terwujdnya masyarakat yang lebih makmur.

Pembangunan menurut Soekanto (2006:382), disamping memiliki tujuantujuan yang diinginkan tidak mustahil pembangunan mengakibatkan terjadinya dampak pada sub sistem kemasyarakatan. 
Dampak tersebut akan timbul apabila terjadi gejala-gejala, antara lain :

a. Perubahan yang cepat;

b. Perubahan sosial, ekonomi dan politik yang simultan;

c. Pencarian faktor kesalahan karena ketidakmampuan membawa perubahan yang cepat.

Dalam pengertian disiplin ekonomi, pembangunan adalah suatu usaha proses yang menyebabkan pendapatan perkapita masyarakat meningkat dalam jangka panjang (Sukirno, 2007:13). Dengan demikian, proses pembangunan terjadi di semua aspek kehidupan masyarakat, ekonomi, sosial, budaya, politik, yang berlangsung pada level makro dan mikro. Makna penting dari pembangunan adalah adanya kemajuan/perbaikan, pertumbuhan dan diversivikasi. Sebagaimana dikemukakan oleh para ahli di atas, pembangunan adalah semua proses perubahan yang terstrukur yang dilakukan melalui upaya-upaya yang sadar dan direncanakan.

\section{Peraturan Pemerintah Nomor 60 Tahun 2008}

Peraturan Pemerintah Nomor 60 Tahun 2008 tentang Sistem Pengendalian Intern Pemerintah merupakan suatu peraturan perundang-undangan di Indonesia yang melaksanakan pengendalian internal pemerintah yang selanjutnya disebut oleh Sistem Pengendalian Intern (SPI) yang diselenggarakan secara menyeluruh di lingkungan pemerintah pusat dan pemerintah daerah. Pengawasan Intern merupakan seluruh proses kegiatan audit, reviu, evaluasi, pemantauan dan kegiatan pengawasan lain terhadap penyelenggaraan tugas dan fungsi organisasi dalam rangka memberikan keyakinan memadai bahwa kegiatan telah dilaksanakan sesuai dengan tolak ukur yang telah ditetapkan secara efektif dan efisien untuk mewujudkan tata kelola pemerintah yang baik.
Secara khusus Peraturan Pemerintah Nomor 60 Tahun 2008 ini menjelaskan pengertian risiko, serta tujuan risiko, manfaat risiko dan proses penilaian risiko. Metode peniliaian risiko dapat dilingkup melalui identifikasi risiko, tujuan dan proses identifikasi serta cara menyusun daftar risiko. Melakukan penilaian risiko dapat dilakukan dengan tahapan identifikasi risiko, analisis risiko dan respon risiko.

\section{METODE PENELITIAN}

Untuk mengetahui manajemen risiko pembangunan infrastruktur, penelitian ini menggunakan jenis penelitian eksplanatori konkuren dengan pendekatan metode campuran. Penelitian campuran adalah penelitian yang menggabungkan penelitian kualitatif dan kuantitatif (Creswell, 2010: 5). Tujuan menggunakan metode penelitian campuran adalah penggunaan metode kuantitatif dan kualitatif untuk digunakan bersama dalam suatu penelitian sehingga menghasilkan data yang lebih komprehensif, dapat diandalkan, obyektif dan valid. Dalam proses penelitian ini peneliti menggunakan strategi eksplanatoris konkruen yaitu untuk mengumpulkan dan menganalisis data kuantitatif dan kualitatif secara bersamaan (simultan) karena menurut peneliti metode ini dianggap efektif lebih cepat dan dapat dipertanggungjawabkan. Oleh karena itu, dalam penelitian campuran, memahami realitas sosial yang sebenarnya sebenarnya tergantung pada makna dan interpretasi yang diberikan oleh manusia yang melihatnya. Oleh karena itu, melalui desain yang sedemikian rupa diperoleh penjelasan dan gambaran/deskripsi.

\section{Hasil Penelitian}

Identifikasi Resiko dan Analisis Resiko

Komponen analisis risiko adalah melakukan analisis risiko menggunakan metode penilaian untuk menilai tingkat risiko dengan frekuensi probabilitas risiko yang terjadi dan dampak risiko pada aspek dominan yang dipilih. Selanjutnya untuk 
mengukur risiko menggunakan rumus persentase Severity Index (SI) adalah sebagai berikut:

$$
\begin{aligned}
& \mathrm{SI}=\frac{\sum_{i=0}^{4} a i x i}{4 \sum_{i=0}^{4} x i}(100 \%) \\
& \text { Keterangan: } \\
& \mathrm{a}_{\mathrm{i}}=\text { konstanta penilaian } \\
& \mathrm{x}_{\mathrm{i}}=\text { frekuensi responden } \\
& \mathrm{i}=0,1,2,3,4, \ldots ., \mathrm{n}
\end{aligned}
$$

$\mathrm{x}_{0}, \mathrm{x}_{1}, \mathrm{x}_{2}, \mathrm{x}_{3}, \mathrm{x}_{4}$ adalah respon frekuensi responden

$$
\mathrm{a}_{0}=0, \mathrm{a}_{1}=1, \mathrm{a}_{2}=2, \mathrm{a}_{3}=
$$

$3, \mathrm{a} 4=4$

$$
\mathrm{x}_{0}=\text { frekuensi responden }
$$

"sangat rendah", maka a $0=0$

$$
\mathrm{x}_{1}=\text { frekuensi responden }
$$

"rendah", maka a $1=1$

$\mathrm{x}_{2}=$ frekuensi responden

"cukup tinggi”, maka a $2=2$

$$
\mathrm{x} 3=\text { frekuensi responden }
$$

"tinggi", maka a3 = 3

$\mathrm{x} 4=$ frekuensi responden "sangat tinggi”, maka a4 $=4$

Dengan penentuan skala sebagai berikut:

Sangat Rendah $=0$

Rendah $=1$

\section{Technical Feasibility}

Risiko kebijakan pembangunan infrastruktur di Institut Teknologi Sumatera jika dilihat melalui indikator Technical Feasibility ada beberapa risiko yang muncul dan dapat dilihat pada tabel sebagai berikut:

Tabel 2. Probalitas Berdasarkan Aspek

Technical Feasibility

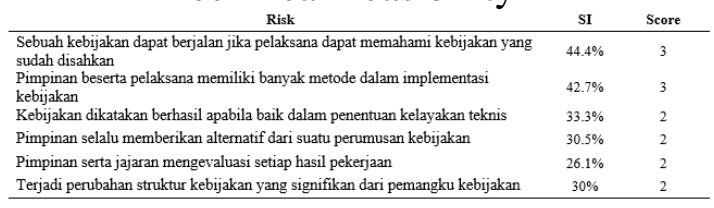

\section{Economic and Financial Possibility}

Risiko kebijakan pembangunan infrastruktur di Institut Teknologi Sumatera jika dilihat melalui indikator Economic and Financial Possibility ada beberapa risiko yang muncul dan dapat dilihat pada tabel sebagai berikut :

Tabel 3. Probalitas Berdasarkan Aspek Economic and Financial Possibility

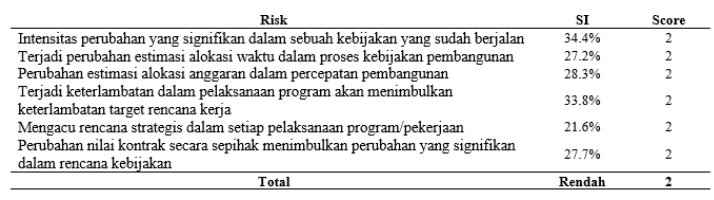

\section{Political Viability}

Risiko kebijakan pembangunan infrastruktur di Institut Teknologi Sumatera jika dilihat melalui indikator Political Viability ada beberapa risiko yang muncul dan dapat dilihat pada tabel sebagai berikut:

Tabel 4. Probalitas Berdasarkan Aspek Political Viability

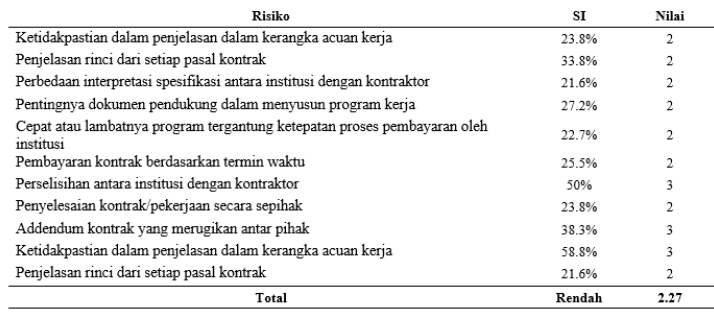

\section{Administrative Operability}

\begin{tabular}{|c|c|c|}
\hline Risiko & SI & Nilai \\
\hline Peran pengawasan melekat dari pimpinan & $23.8 \%$ & 2 \\
\hline Komitmen pengawasan oleh seluruh stakeholder & $33.3 \%$ & 2 \\
\hline Kesesuaian arah kebijakan dengan rencana strategis pemerintah & $22.2 \%$ & 2 \\
\hline Hubungan serta koordinasi berbagai pihak & $23.8 \%$ & 2 \\
\hline Pengalaman SDM dalam menjalankan kebijakan & $32.7 \%$ & 2 \\
\hline Penerapan Standar Operasional Prosedur (SOP) yang sudah sesuai & $26.6 \%$ & 2 \\
\hline Produktivitas kinerja SDM dalam melaksanakan kebijakan & $24.4 \%$ & 2 \\
\hline Total & Rendah & 2 \\
\hline
\end{tabular}

Risiko kebijakan pembangunan infrastruktur di Institut Teknologi Sumatera jika dilihat melalui indikator Administrative Operability ada beberapa risiko yang muncul dan dapat dilihat pada tabel sebagai berikut:

Tabel 5. Probalitas Berdasarkan Aspek Administrative Operability 


\section{Pembahasan Penelitian}

Setelah melakukan penilaian risiko, kemudian dilakukan menggambar atau memetakan hasil penilaian risiko ke dalam diagram matriks berdasarkan frekuensi probabilitas dan dampak. Untuk mengukur risiko, gunakan rumus :

$$
\mathrm{R}=(\mathrm{P}) \times(\mathrm{I})
$$

Keterangan:

$\mathrm{R}=$ tingkat risiko

$\mathrm{P}=$ Probabilitas risiko yang terjadi

I = tingkat dampak yang terjadi

Skala yang digunakan untuk mengukur potensi risiko terhadap frekuensi dan dampak risiko adalah skala likert menggunakan rentang angka 1 hingga 5, yaitu:

Pengukuran probabilitas risiko $(\mathrm{P})$ :

$1=$ sangat jarang

$2=$ langka

$3=$ cukup

$4=$ sering

$5=$ sangat sering

Pengukuran dampak risiko (I):

$1=$ sangat kecil

$2=$ kecil

$3=$ sedang

4 = besar

$5=$ sangat besar

Analisis probabilitas $\mathrm{x}$ dampak dari aspek Technical Feasibility perhitungan dilakukan dengan mengalikan penilaian probabilitas dengan penilaian dampak risiko dari aspek Kelayakan Teknis. Berikut ini adalah hasil dari probabilitas $\mathrm{x}$ dampak pada aspek Technical Feasibility dalam bentuk tabel sebagai berikut :
Tabel 6. dampak pada aspek Technical Feasibility

\begin{tabular}{|c|c|c|c|c|c|}
\hline No & Jenis Risiko & $\begin{array}{c}\mathbf{P} \\
\text { Probabilitas }\end{array}$ & $\begin{array}{c}\text { I } \\
\text { Dampak }\end{array}$ & PXI & $\begin{array}{c}\text { Kategori } \\
\text { Risiko }\end{array}$ \\
\hline A & TECHNICAL FEASIBILITY & & & & \\
\hline 1 & $\begin{array}{l}\text { Sebuah kebijakan dapat berjalan jika pelaksana dapat } \\
\text { memahami kebijakan yang sudah disahkan }\end{array}$ & 3 & 3 & 9 & Sedang \\
\hline 2 & $\begin{array}{l}\text { Pimpinan beserta pelaksana memiliki banyak metode } \\
\text { dalam implementasi kebijakan }\end{array}$ & 3 & 4 & 12 & Tinggi \\
\hline 3 & $\begin{array}{l}\text { Kebijakan dikatakan berhasil apabila baik dalam } \\
\text { penentuan kelayakan teknis }\end{array}$ & 2 & 2 & 4 & Rendah \\
\hline 4 & $\begin{array}{l}\text { Pimpinan selalu memberikan alternatif dari suatu } \\
\text { perumusan kebijakan }\end{array}$ & 2 & 2 & 4 & Rendah \\
\hline 5 & $\begin{array}{l}\text { Pimpinan serta jajaran mengevaluasi setiap hasil } \\
\text { pekerjaan }\end{array}$ & 2 & 2 & 4 & Rendah \\
\hline 6 & $\begin{array}{l}\text { Terjadi perubahan struktur kebijakan yang signifikan } \\
\text { dari pemangku kebijakan }\end{array}$ & 2 & 2 & 4 & Rendah \\
\hline в & ECONOMIC AND FINANCIAL POSSIBILITY & & & & \\
\hline 7 & $\begin{array}{l}\text { Intensitas perubahan yang signifikan dalam sebuah } \\
\text { kebijakan yang sudah berjalan }\end{array}$ & 2 & 3 & 6 & Rendah \\
\hline 8 & $\begin{array}{l}\text { Terjadi perubahan estimasi alokasi waktu dalam } \\
\text { proses kebijakan pembangunan }\end{array}$ & 2 & 3 & 6 & Rendah \\
\hline 9 & $\begin{array}{l}\text { Perubahan estimasi alokasi anggaran dalam } \\
\text { percepatan pembangunan }\end{array}$ & 2 & 2 & 4 & Rendah \\
\hline 10 & $\begin{array}{l}\text { Terjadi keterlambatan dalam pelaksanaan program } \\
\text { akan menimbulkan keterlambatan target rencana kerja }\end{array}$ & 2 & 2 & 4 & Rendah \\
\hline 11 & $\begin{array}{l}\text { Mengacu rencana strategis dalam setiap pelaksanaan } \\
\text { program/pekerjaan }\end{array}$ & 2 & 2 & 4 & Rendah \\
\hline 12 & $\begin{array}{l}\text { Perubahan nilai kontrak secara sepihak menimbulkan } \\
\text { perubahan yang signifikan dalam rencana kebijakan }\end{array}$ & 2 & 2 & 4 & Rendah \\
\hline $\mathrm{c}$ & POLITICAL VIaBILITY & & & & \\
\hline 13 & $\begin{array}{l}\text { Ketidakpastian dalam penjelasan dalam kerangka } \\
\text { acuan kerja }\end{array}$ & 2 & 2 & 4 & Rendah \\
\hline 14 & Penjelasan rinci dari setiap pasal kontrak & 2 & 2 & 4 & Rendah \\
\hline 15 & $\begin{array}{l}\text { Perbedaan interpretasi spesifikasi antara institusi } \\
\text { dengan kontraktor }\end{array}$ & 2 & 2 & 4 & Rendah \\
\hline 16 & $\begin{array}{l}\text { Pentingnya dokumen pendukung dalam menyusun } \\
\text { program kerja }\end{array}$ & 2 & 2 & 4 & Rendah \\
\hline 17 & $\begin{array}{l}\text { Cepat atau lambatnya program tergantung ketepatan } \\
\text { proses pembayaran oleh institusi }\end{array}$ & 2 & 2 & 4 & Rendah \\
\hline 18 & Pembayaran kontrak berdasarkan termin waktu & 3 & 2 & 6 & Rendah \\
\hline 19 & Perselisihan antara institusi dengan kontraktor & 2 & 3 & 6 & Rendah \\
\hline 20 & Penyelesaian kontrak/pekerjaan secara sepihak & 2 & 2 & 4 & Rendah \\
\hline 21 & Addendum kontrak yang merugikan antar pihak & 2 & 3 & 6 & Rendah \\
\hline 22 & $\begin{array}{l}\text { Institusi mendapat dukungan dari pihak masyarakat } \\
\text { dan civil society }\end{array}$ & 3 & 3 & 9 & Sedang \\
\hline 23 & $\begin{array}{l}\text { Kebermanfaatan berkelanjutan pembangunan untuk } \\
\text { masyarakat }\end{array}$ & 2 & 2 & 4 & Rendah \\
\hline D & & & & & \\
\hline 24 & npin: & 2 & 2 & 4 & Rendah \\
\hline
\end{tabular}

Pembahasan selanjutnya adalah analisis probabilitas $\mathrm{x}$ dampak pada aspek Political Viability dari perhitungan dilakukan dengan mengalikan penilaian probabilitas dengan penilaian dampak risiko dari aspek Political Viability. Berikut adalah hasil dari probabilitas $\mathrm{x}$ dampak pada aspek Political Viability dalam bentuk tabel sebagai berikut: 
Tabel 7. dampak pada aspek Political Viability

\begin{tabular}{|c|c|c|c|c|c|}
\hline No & Jenis Risiko & $\begin{array}{c}\mathbf{P} \\
\text { Probabilitas }\end{array}$ & $\begin{array}{c}\text { I } \\
\text { Dampak }\end{array}$ & PXI & $\begin{array}{c}\text { Kategori } \\
\text { Risiko }\end{array}$ \\
\hline A & TECHNICAL FEASIBILITY & & & & \\
\hline 1 & $\begin{array}{l}\text { Sebuah kebijakan dapat berjalan jika pelaksana dapat } \\
\text { memahami kebijakan yang sudah disahkan }\end{array}$ & 3 & 3 & 9 & Sedang \\
\hline 2 & $\begin{array}{l}\text { Pimpinan beserta pelaksana memiliki banyak metode } \\
\text { dalam implementasi kebijakan }\end{array}$ & 3 & 3 & 9 & Sedang \\
\hline 3 & $\begin{array}{l}\text { Kebijakan dikatakan berhasil apabila baik dalam } \\
\text { penentuan kelayakan teknis }\end{array}$ & 2 & 2 & 4 & Rendah \\
\hline 4 & $\begin{array}{l}\text { Pimpinan selalu memberikan alternatif dari suatu } \\
\text { perumusan kebijakan }\end{array}$ & 2 & 2 & 4 & Rendah \\
\hline 5 & $\begin{array}{l}\text { Pimpinan serta jajaran mengevaluasi setiap hasil } \\
\text { pekerjaan }\end{array}$ & 2 & 2 & 4 & Rendah \\
\hline 6 & $\begin{array}{l}\text { Terjadi perubahan struktur kebijakan yang signifikan } \\
\text { dari pemangku kebijakan }\end{array}$ & 2 & 2 & 4 & Rendah \\
\hline в & ECONOMIC AND FINANCIAL POSSIBILITY & & & & \\
\hline 7 & $\begin{array}{l}\text { Intensitas perubahan yang signifikan dalam sebuah } \\
\text { kebijakan yang sudah berjalan }\end{array}$ & 2 & 3 & 6 & Rend \\
\hline 8 & $\begin{array}{l}\text { Terjadi perubahan estimasi alokasi waktu dalam } \\
\text { proses kebijakan pembangunan }\end{array}$ & 2 & 3 & 6 & Ren \\
\hline 9 & $\begin{array}{l}\text { Perubahan estimasi alokasi anggaran dalam } \\
\text { percepatan pembangunan }\end{array}$ & 2 & 2 & 4 & Rendah \\
\hline 10 & $\begin{array}{l}\text { Terjadi keterlambatan dalam pelaksanaan program } \\
\text { akan menimbulkan keterlambatan target rencana kerja }\end{array}$ & 2 & 2 & 4 & Rendah \\
\hline 11 & $\begin{array}{l}\text { Mengacu rencana strategis dalam setiap pelaksanaan } \\
\text { program/pekerjaan }\end{array}$ & 2 & 2 & 4 & $\operatorname{Rer}$ \\
\hline 12 & $\begin{array}{l}\text { Perubahan nilai kontrak secara sepihak menimbulkan } \\
\text { perubahan yang signifikan dalam rencana kebijakan }\end{array}$ & 2 & 2 & 4 & Rendah \\
\hline $\mathrm{c}$ & POLITIC & & & & \\
\hline 13 & $\begin{array}{l}\text { Ketidakpastian dalam penjelasan dalam kerangka } \\
\text { acuan kerja }\end{array}$ & 2 & 2 & 4 & Rendah \\
\hline 14 & Penjelasan rinci dari setiap pasal kontrak & 2 & 2 & 4 & Rendah \\
\hline 15 & $\begin{array}{l}\text { Perbedaan interpretasi spesifikasi antara institusi } \\
\text { dengan kontraktor }\end{array}$ & 2 & 2 & 4 & Rendah \\
\hline 16 & $\begin{array}{l}\text { Pentingnyaa dokumen pendukung dalam menyusun } \\
\text { program kerja }\end{array}$ & 2 & 2 & 4 & Rendah \\
\hline 17 & $\begin{array}{l}\text { Cepat atau lambatnya program tergantung ketepatan } \\
\text { proses pembayaran oleh institusi }\end{array}$ & 3 & 2 & 6 & Rendah \\
\hline 18 & Pembayaran kontrak berdasarkan termin waktu & 2 & 2 & 4 & Rendah \\
\hline 19 & Perselisihan antara institusi dengan kontraktor & 2 & 4 & 8 & Sedang \\
\hline 20 & Penyelesaian kontrak/pekerjaan secara sepihak & 2 & 3 & 6 & Rendah \\
\hline 21 & Addendum kontrak yang merugikan antar pihak & 2 & 2 & 4 & Rendah \\
\hline 22 & $\begin{array}{l}\text { Institusi mendapat dukungan dari pihak masyarakat } \\
\text { dan civil society }\end{array}$ & 3 & 3 & 9 & Sedang \\
\hline 23 & $\begin{array}{l}\text { Kebermanfaatan berkelanjutan pembangunan untuk } \\
\text { masyarakat }\end{array}$ & 2 & 2 & 4 & Rend \\
\hline $\begin{array}{c}\mathbf{D} \\
24\end{array}$ & $\begin{array}{l}\text { ADMINISTRATIVE OPERABILITY } \\
\text { Peran pengawasan melekat dari pimpinan }\end{array}$ & 2 & 2 & 4 & Rendah \\
\hline 25 & Komitmen pengawasan oleh seluruh stakeholder & 2 & 2 & 4 & Rendah \\
\hline
\end{tabular}

\section{Respon Risiko}

Untuk menangani risiko baik risiko internal dan eksternal membutuhkan mitigasi risiko. Mitigasi risiko merupakan tindakan korektif yang direncanakan secara berkelanjutan yang dilakukan oleh seseorang yang memiliki kewenangan untuk mengurangi dampak dari suatu kejadian yang berpotensi atau membahayakan institusi tersebut.

Risiko eksternal yakni perselisihan antara institusi dengan kontraktor sehingga menimbulkan aksi demo di kampus maka tindakan mitigasi dari aktor kebijakan melakukan sosialisasi, koordinasi dan komunikasi dengan baik antara kontraktorinstitusi dan institusi-lembaga masyarakat.

Sedangkan risiko internal yaitu kebijakan dapat berjalan dengan baik jika pegawai dapat memahami kebijakan yang sudah disahkan maka tindakan mitigasi berupa pentingnya peran pimpinan dalam memberikan saran beserta masukan yang baik sehingga dalam melaksanakan kebijakan para staf memiliki banyak metode-metode yang baik sehingga tidak berbenturan dengan hukum dalam melaksanakan kebijakan.

\section{SIMPULAN}

Analisis risiko yang dilakukan dihitung berdasarkan kelayakan teknis dan aspek kelayakan politik dan hukum berdasarkan probabilitas yang muncul. Risiko signifikan berdasarkan aspek kelayakan teknis, yaitu suatu kebijakan dapat berjalan jika karyawan dapat memahami kebijakan yang telah disahkan sebesar $56,6 \%$ berarti risiko sedang, maka kepemimpinan dan karyawan memiliki banyak metode dalam menerapkan kebijakan $65,5 \%$ yang berarti risiko tinggi, maka institusi mendapat dukungan dari masyarakat dan masyarakat sipil sebesar 53,5\% yang berarti risiko sedang. Risiko signifikan berdasarkan aspek kelayakan politik dan hukum yaitu suatu kebijakan dapat berjalan jika karyawan dapat memahami kebijakan yang telah disetujui sebesar $49,4 \%$ berarti risiko sedang, maka kepemimpinan dan karyawan memiliki banyak metode dalam menerapkan kebijakan sebesar $46,6 \%$ yang berarti sedang risiko, kemudian perselisihan antara lembaga dan kontraktor sebesar $62,7 \%$ berarti risiko tinggi, maka lembaga tersebut mendapat dukungan dari masyarakat dan masyarakat sipil sebesar $59,4 \%$ berarti risiko sedang.

Respon risiko terhadap risiko dominan yang timbul adalah risiko eksternal, yaitu perselisihan antara institusi dan kontraktor, yang menyebabkan demonstrasi di kampus, sehingga para pelaku kebijakan melakukan sosialisasi, koordinasi dan komunikasi yang baik antara kontraktor dan lembaga masyarakat. Risiko internal, yaitu kebijakan dapat berjalan dengan baik jika karyawan dapat memahami kebijakan yang telah disahkan. Pentingnya peran kepemimpinan dalam memberikan saran 
bersama dengan masukan yang baik sehingga dalam menerapkan kebijakan para bawahan memiliki banyak metode yang baik untuk menerapkan kebijakan.

\section{DAFTAR PUSTAKA}

Buku:

Bardach, Eugene. 2016. A Practical Guide For Policy Analysis The Eight Fold Path To More Effective Problem Solving. Washington DC: Sage Publications.

Baswori dan Suwandi. 2008. Memahami Penelitian Kualitatif. Jakarta: Rineka Cipta.

Bryman, Alan. 2012. Social Research Methods. New York: Oxford University Press.

Creswell, John C. 2010. Design Research: Pendekatan Kuantitatif, Kualitatif dan Campuran. Yogyakarta: Pustaka Pelajar.

Dinham, Adam. 2009. Faith, Public Policy and Civil Society: Problems, Policies, Controversies. London: Palgarave Macmillan.

Fischer, Frank dkk. 2007. Handbook of Public Policy Analysis: Theory, Politics and Methods. Pennsylvania: CRC Press.

Flick, Uwe dkk. 2014. A Companion to Qualitative Research. London: Sage Publications.

Halperin, Sandra \& Heath, Oliver. 2012. Political Research: Methods and Practical Skills. New York: Oxford University Press.

Hamdi, Muchlis. 2014. Kebijakan Publik: Proses, Analisis dan Partisipasi. Bogor: Ghalia Indonesia.

Kerzner, Harold. 2001. Project Management: A System Approach to Planning, Schedulling and Controlling. New Jersey: John Wiley \& Sons Incorporated.
Madani, Muhlis. 2011. Interaksi Aktor Dalam Proses Perumusan Kebijakan Publik. Yogyakarta: Graha Ilmu.

Moeller, Robert R. 2011. COSO Enterprise Risk Management (Establishing Effective Governance, Risk dan Compliance Processes) Second Edition. New Jersey: John Willey \& Sons Inc.

Neuman, W Laurence. 2014. Social Research Methods: Qualitative and Quantitative Approaches. Boston: Pearson Education Limited.

Nugroho, Riant. 2017. Kebijakan Publik Untuk Negara Berkembang: Model Perumusan, Implementasi dan Evaluasi. Jakarta: PT Elex Media Komputindo.

Parsons, Wayne. 2014. Public Policy: Pengantar Teori dan Praktik Analisis Kebijakan. Jakarta: Kencana.

Soekanto, Soerjono. 2006. Beberapa Permasalahan Hukum dalam Kerangka Pembangunan di Indonesia. Depok: UI Press.

Sugiyono. 2014. Metode Penelitian Pendidikan Pendekatan Kuantitatif, Kualitatif, dan R \& D. Alfabeta: Bandung.

Suharno. 2013. Dasar-dasar Kebijakan Publik: Kajian Proses dan Analisis Kebijakan. Yogyakarta: Penerbit Ombak.

Suharto, Edi. 2008. Analisis Kebijakan Publik. Bandung: Alfabeta.

Sukirno, Sadono. 2007. Ekonomi Pembangunan: Proses Masalah dan Dasar Kebijakan. Jakarta: Kencana.

\section{Jurnal:}

Dandage, Rahul (dkk). 2018. Strategy Development for International Project Risk Management Based on Prioritization of Risk Categories. 
Dewi, Eka Sari. 2011. Analisa Risiko Pada Pelaksanaan Proyek Pembangunan Box Culvert di Surabaya.

Laurentiu, Romanescu Marcel. 2016. The Analysis of Risk Management Process Within Management.

Mulyarko, Lazuardi Gagah. 2015. Pengaruh Risiko Pada Kontrak Kerja Konstruksi Terhadap Biaya Pekerjaan Jalan Tol Bogor Ring Road II.

Park. Young H. 2010. A Study of Risk Management and Performance Measures on New Product Development.

Yan, Y. dan Nettayanun, S. 2019. Strategic Risk Management in the Chinese Property and Casualty Insurance Industry.

\section{Dokumen Lainnya :}

Peraturan Pemerintah Nomor 60 Tahun 2008 tentang Sistem Pengendalian Intern Pemerintah.

Memorandum of Understanding Kerjasama Pengembangan Institusi ITERA oleh ITB tertanggal 23 Desember 2015.

www.itb.ac.id/news/read/5015/home/itbdan-itera-resmikan-kerja-samapengembangan-institusi accessed on 17 Januari 2020 Pukul 17.00 WIB

https://radarlampung.co.id/2019/06/20/mas sa-demo-soroti-pembangunanlaboratorium-teknik-itera/ accessed on 17 Januari 2020 Pukul 16.50 WIB 
Halaman Kosong 